\title{
The second-home rental market: a hedonic analysis of the effect of different characteristics and a high-market-share intermediary on price
}

\author{
AlberT SALÓ
}

ESADE Business School, Av Torre Blanca, 59, 08172 Sant Cugat del Vallès, Barcelona, Spain.E-mail: albert.salo@esade.edu. (Corresponding author.)

\section{ANNA GARRIGA}

Facultat de Ciències Econòmiques i Empresarials, Universitat de Girona, Campus Montilivi, 17071 Girona, Spain. E-mail: anna.garriga@udg.edu.

\begin{abstract}
The phenomenon of second homes has been little studied in the tourism economics literature. Residential tourism can represent more than $50 \%$ of housing in tourist areas like the Costa Brava in Spain. This article uses hedonic techniques to analyse the market value of the attributes that explain the overall price of a representative sample of second-home rentals. The explanatory variables of this overall price include characteristics such as number of rooms, housing area size, garden size, swimming pool, housing type, distribution channel, municipality, sea views, distance to the beach and seasonality. This study therefore provides tools to assist the decision making of the main agents involved: stakeholders and policy makers.
\end{abstract}

Keywords: residential tourism; hedonic prices; private and public services; seasonality; housing market

Second residences make up one of the largest segments of the tourist accommodation market. The rented holiday homes market has grown in Spain in recent years as it offers an alternative way to increase the number of available beds for the still growing number of tourists that visit the country year after year. However, it is also one of the least studied when compared with the amount of empirical evidence available on other types of accommodation, especially hotels. Nowadays, this sector is important in Spain, where $16 \%$ of all dwellings are officially classified as second homes. Besides, another $14.8 \%$ are considered unoccupied or not classified and most of these are considered potential second homes (Vinuesa, 2005). ${ }^{1}$

In spite of its importance, little is known about the determinants of the prices of second homes in the rental market. In this paper, the main goal is 
to find out what are the principal attributes that influence the final prices of rental tourist second homes using hedonic price methods, developed theoretically by Rosen (1974). To do so, this article analyses one of the most popular tourist destinations in Spain, the Costa Brava, a region made up of 23 coastal municipalities on the north-east coast. In this local area, the market share of second homes in accommodation for the tourist market is more than $50 \%$ of total beds, followed by hotels, campsites, bed and breakfast and so on (Saló, 2005).

The hedonic method literature has focused basically on hotels in tourist accommodation, mainly because of better data availability and reliability. In the recent literature, there are several examples, such as Espinet et al (2003), Haroutunian et al (2005), Thrane (2005), Hamilton (2007) and Rigall-I-Torrent and Fluvià (2011), that mainly use tour operators' brochures to find out the price determinants of holiday packages in different destinations according to various tour operators.

Moreover, the hedonic approach has been used in Pompe and Rinehart (1994) and Benson et al (1998) in order to uncover a shadow price for the value of both beach and a view with regards to housing property. In this context, Bover and Velilla (2002) try to explain housing inflation in property dwellings in Spain, adjusting for quality changes using alternative hedonic techniques to control for unobserved housing characteristics such as precise location, transport, closeness to services and so on. However, the second-homes rental market has remained unexplored, regardless of this significance.

Nevertheless, this paper should be considered as an extension of the existing literature on second homes. For instance, Coppock (1977), Müller et al (1994) and Marjavaara and Müller (2007) analyse the positive and negative impacts of several elements. There is a wide range of topics considered in terms of economic, environment and social effects. In this context, this paper is grounded in economics.

The article is divided into six sections. In the first section, the original main hypotheses are presented in order to clarify the contribution of this paper in the tourist hedonic pricing literature. The paper follows with an analysis of hedonic techniques studying the chosen variables and the models set out to explain rental prices (dependent variable) according to the characteristics of the holiday home (independent variables). In the third section, collected data are studied, as well as the seasonality of rental prices. In the subsequent section, the results are presented and interpreted in detail. In the fifth section there is an extension of the influence of intermediaries in the market supported by a theoretical framework. In the sixth section a further discussion is exposed in terms of checking the original hypothesis, whereas public and private policy implications are also provided. Finally, the conclusions summarize the most significant findings.

\section{Hypothesis and questions to contrast}

Through the hedonic hypothesis introduced by Rosen (1974) and technically enhanced by Berndt (1990), studying the features of second homes can be useful as some values can be found to have effects on final price. These values may 
also be appreciated by local policy makers and stakeholders, as well as consumers. Therefore, some new main hypotheses are examined here in relation to the attributes that might have a significant influence on the final price of rental second homes but which have been barely studied in the hotel market.

- Beach distance effect. There is evidence on the importance of being located on the coast or being far away from it. The significant differences in price according to location with regard to the beach are analysed. This paper considers whether there is a gradual scale where prices increase significantly when the location of second homes approaches the coast. Until now, in hotel analysis the assumption was based only on being in front of the sea or otherwise. Second homes provide more flexibility because their locations are more dispersed than hotels, which are normally concentrated in certain areas.

- Sea views effect. It is well known that hotels charge an extra rate for rooms with sea views from the balcony, terrace or windows, but it is not easy to estimate the value of this variable when there are different kinds of rooms in the same hotel. In second homes, one can find out whether there is a high or low gap in price because of enjoying a coast landscape or otherwise. Whatever the result, it is useful information in order to analyse the value of the coast according to the market.

- Housing type. A peculiarity of the second-homes rental market allows comparing whether the type of construction (detached house, terraced house or apartment) affects the price. A detached house would seem the most expensive type because of the privacy it offers.

- Role of intermediaries. The distribution channel is considered a key variable in this paper. The recent growth in the second-home market and the heterogeneity of demand implies that there are several channels to rent a second home. Thus, this selection could affect the final price.

- Other relevant effects. Other characteristics analysed in the hedonic literature on both hotel accommodation and housing, such as inside and outside feature effects, municipality effects or seasonality effects, are compared here. The possibility of contrasting these results with hotels could be a relevant analysis for future research.

\section{Evaluating the characteristics of second-home rentals: hedonic price methods}

\section{Preliminaries}

Hedonic price methods are based on the idea that goods or services can be seen as a bundle of characteristics or attributes and are valued for these characteristics. Second homes with tourist and housing characteristics fit in this model introduced by Rosen (1974). According to Sinclair et al (1990), a product A can be written as:

$$
A=\left(A_{1}, A_{2}, A_{3}, \ldots, A_{n}\right)
$$

where $A_{i}$ is the quantity or value of $i$ th characteristic. Because the overall price is assumed to be a function of its attributes, the hedonic price function can be considered as follows: 


$$
P(A)=P\left(A_{1}, A_{2}, A_{3}, \ldots, A_{n}\right)
$$

This set of characteristics determines the choices of consumers according to their utility. Therefore, the price of the goods can be broken down into the implicit prices of these characteristics. Hedonic methods have been employed to ascertain what attributes have a significant effect on the price of rooms. In this setting, different characteristics have been included in the analysis.

Location is a key variable when the housing market is analysed. Bover and Velilla (2002) consider location as one of the most important variables in big and crowded cities, because of access to the main services. In coastal areas, Pompe and Rinehart (1994) and Benson et al (1998) consider location with respect to the coast within a municipality as a main variable when considering housing property data. This paper presents evidence on location as a significant determinant of the final price in the second-home rental market.

Another interesting variable is the commercialization channel or the intermediaries' role on destinations through tour operators or other channels (Sinclair et al, 1990; Espinet et al, 2003; Haroutunian et al, 2005; Thrane, 2005). In the following sections, a theoretical framework is set up in order to justify some empirical results obtained in this paper.

\section{The model}

The relevant characteristics that influence rented tourist accommodation are considered according to the aforementioned literature. These selected characteristics are based on the experience of hedonic approaches to both property dwellings and hotel accommodation and are listed appropriately as follows:

- Inside and outside housing characteristics only: number of bedrooms, house size in increments (small, medium, large), private garden/terrace/balcony size through increments (small, medium, large) and common garden/area. ${ }^{2}$

- Both tourist and housing characteristics: type of accommodation (detached house, terraced house or apartment), availability of car park and swimming pool.

- Tourist characteristics only: second-home rental intermediary (wholesaler or others), star rating (only available for wholesaler data), sea views, distance to the nearest beach and municipality.

In the data sample, lack of information from brochures is to blame for other variables not being included to run hedonic regressions in the next sections. ${ }^{3}$

In accordance with the approach commonly used in the literature, a semilogarithmic specification has been chosen. This specification allows an easy interpretation of the coefficients in a context where most of the independent variables are dummies. The following model is estimated by means of OLS regression:

$$
\begin{aligned}
& \ln \text { price }_{i t}=\beta_{0}+\Sigma \beta_{i} D_{i}^{i o c}+\Sigma \alpha_{i} D_{i}^{l o c}+\Sigma \psi_{i} D_{i}^{\text {cha }}+\Sigma \omega_{i} D_{i t}^{\text {sed }}+u_{i t} \\
& i=1, \ldots, N \\
& \mathrm{t}=1, \ldots, T
\end{aligned}
$$


where $i$ identifies each second-home accommodation and $t$ is the holiday period according to the seasonality variable. Also, $\ln$ price $_{i t}$ is the natural logarithm of the price; $\beta_{0}$ is the constant that represents the rental price of accommodation without any bedrooms and with characteristics related to the reference categories of the dummy variables studied. The term $\Sigma \beta_{i} D_{i}^{i o c}$ refers to the coefficients of the inside and outside characteristics of the accommodation (number of rooms, size in square metres, size of private garden or terrace in square metres, common garden, car park, swimming pool and type of housing - apartment, terraced house or detached house).

The term $\Sigma \alpha_{i} D_{i}^{l o c}$ represents the coefficients of the variables that refer to the location of the accommodation, such as if there is a sea view, the distance to the nearest beach and the municipality where it is located. The ten most representative municipalities in the area have been included finally in the regression according to proportional sampling. The term $\Sigma \psi_{i} D_{i}^{\text {cha }}$ explains the effect that the different distribution channels (intermediaries) can have on the final price of the accommodation, differentiating between an intermediary wholesaler's brochure and different intermediaries from the Internet. A time variable $\Sigma \omega_{i} D_{i t}^{\text {sea }}$ is introduced to study the seasonality of the rental price (according to the six holiday periods mentioned subsequently). Finally, the perturbation term $u_{i t}$ is normally distributed with mean 0 and constant variance $\sigma_{u}^{2}$.

In this model, the shadow prices of the characteristics studied are considered to remain constant throughout the time period of the sample (2004). Obviously, the hypothesis that the quality will not vary throughout the year is also applied (Berndt, 1990). Therefore, the following specification is broken down as:

$$
\begin{aligned}
& \ln _{\text {price }_{i t}}=\beta_{0}+\beta_{1} \text { rooms }+\sum_{i=2}^{3} \beta_{i} m^{2} \text { area }+\sum_{i=4}^{5} \beta_{i} m^{2} \text { terrace }+\beta_{6} \text { comgarden }+ \\
& \sum_{i=7}^{8} \beta_{i} \text { bousingtype }+\beta_{9} \text { carpark }+\beta_{10} \text { swimpool }+\sum_{i=11}^{15} \beta_{i} \text { distbeach }+\beta_{16} \text { seaviews }+ \\
& \sum_{i=17}^{25} \beta_{i} \text { municipality }+\beta_{26} \text { intermediary }+\sum_{i=27}^{31} \beta_{i} \text { seasonality }_{i t}+u_{i t}
\end{aligned}
$$

where $\beta_{i}$ defines the parameters to be estimated for each of the characteristics studied. The number of rooms is the only quantitative variable and the rest are qualitative or dummy variables. In the case of the dummies, the percentage variation from the final price is compared to a dummy characteristic with respect to another characteristic of the same dummy, which is chosen as a reference in a ceteris paribus condition. Quantitative variables transformed to dummies (area in square metres, terrace in square metres and distance to the beach) have been created in equal increments in order to interpret coefficients in a better way. A more detailed description of the variables used in this model is given in Table 1.

Two hedonic regressions are carried out, one for the entire set of holiday homes and the other only for accommodation managed by a wholesaler. The second regression uses data from the wholesaler's brochure, which make up 69\% of the whole sample. A star rating is available in this brochure in a similar context to hotel analysis (from 1-star to 4-star rating). ${ }^{4}$ Therefore, this new valuable dummy variable is added and requires running a second regression and analysing the response among the independent remaining variables. According to the brochure, the star category includes several items about observed but 
Table 1. Description of variables used in the hedonic regression.

Variable Coded name Description

Rooms

Home size

\section{Rooms}

size home: less $50 \mathrm{~m}^{2}$

size home: $50-100 \mathrm{~m}^{2}$

size home: $101 \mathrm{~m}^{2}$ and more

Terrace/garden size terrace/garden: less $10 \mathrm{~m}^{2}$

terrace/garden: 10-30 $\mathrm{m}^{2}$ terrace/garden: $31 \mathrm{~m}^{2}$ and more

Common garden

Housing type

Car park

Swimming pool

Beach distance

common garden

terraced house

detached house

apartment

car park

swimming pool

beach distance: $0-30 \mathrm{~m}$ beach distance: $30-100 \mathrm{~m}$

beach distance: 101-300 m

beach distance: $301-1,000 \mathrm{~m}$

beach distance: 1,001-3,000 m

beach distance: 3,001-5,000 m

beach distance: 5,001 $\mathrm{m}$ and more

sea views

Sea views

Physical location

(municipality)

Castelló d'Empúries

Begur

l'Escala

l'Estartit

Llançà

Lloret

Castell-Platja d'Aro

Roses

Calonge

St Feliu de Guixols

Commercialization wholesaler

channel

(intermediaries) Internet

Time period low season

medium season

medium-high season
Number of rooms available

Less than $50 \mathrm{~m}^{2}$ home (used as a reference)

Between 50-100 $\mathrm{m}^{2}$ home

More than $100 \mathrm{~m}^{2}$ home

Less than $10 \mathrm{~m}^{2}$ terrace or garden (used as a reference)

Between 10 and $30 \mathrm{~m}^{2}$ terrace or garden

More than $30 \mathrm{~m}^{2}$ terrace or garden

Availability of common garden

Terraced house (used as a reference)

Detached house

Apartment

Availability of car park

Availability of swimming pool

Home in front of the beach until $30 \mathrm{~m}$

Home between 30 and $100 \mathrm{~m}$ from the beach

Home between 101 and $300 \mathrm{~m}$ from the beach

Home between 301 and 1,000 m from the beach

Home between 1,001 and 3,000 $\mathrm{m}$ from the beach

Home between 3,001 and 5,000 $\mathrm{m}$ from the beach

Home 5,001 or more metres from the beach (used as a reference)

Sea views from the home

Home located in Castelló d'Empúries

Home located in Begur

Home located in l'Escala

Home located in l'Estartit

Home located in Llançà

Home located in Lloret

Home located in Castell-Platja d'Aro

Home located in Roses

Home located in Calonge

Home located in St Feliu de Guixols

Data drawn from a high-market-share wholesaler $(60 \%)$

Data extracted from Internet (31\%) (used as a reference)

Price effect analysis for a bome rented in a low season period (used as a reference)

Effect on price for a home rented in a medium season period

Effect on price for a home rented in a medium-high season period 
Table 1 continued.

\begin{tabular}{lll}
\hline Variable & Coded name & Description \\
& high season & Effect on price for a home rented in a high \\
season period & Effect on price for a home rented in a \\
& upper-high season & Effect on price for a home rented in an \\
& extreme-high season & Ontreme-high season period \\
Star rating & 1-star quality & Two-star home rating \\
(only with & 2-star quality & Three-star home rating \\
wholesaler data) & 3-star quality & Four-star home rating \\
& 4-star quality & .
\end{tabular}

Note: Items in italics were used as a reference in the econometric analysis.

especially non-observed attributes such as comfort, furniture quality, noise level and so on.

\section{Data sample and time period selection}

\section{Data sample}

A database for 2004 provides the weekly price of second-home rentals and also a series of characteristics. In total, we have 1,002 observations. Most of the information on rental prices is available for every week of the year (except November and the first fortnight of December). In some cases, prices are only available for the summer season and other holiday periods, including Christmas, Easter and long weekends.

This sample has been made up across the municipalities of Costa Brava using a stratified sample based on official statistics (number of rented second homes and beds per municipality, see Table 2). The complexity of the sector and the difficulty in obtaining reliable data were the main hurdles encountered when creating a representative sample of a type of tourist accommodation that has hardly been analysed empirically before.

As shown in Table 2, Castelló d'Empúries, Castell-Platja d'Aro, Lloret de Mar, Torroella de Montgrí and l'Escala are the towns with the highest number of official rented apartments and the most beds (above 35\% in the area). These data have been drawn from an intermediary wholesaler's brochure (69\%) and Internet intermediaries (31\%).

\section{Time period selection}

A descriptive analysis of seasonality was performed as a first attempt to analyse the prices of second homes. Thus, the overall average price for each week of the year was calculated. One-way ANOVA analysis has been used to distinguish six different seasons throughout the year, with significant differences in prices. This is shown graphically in Figure 1. Weeks are grouped as follows: 
Table 2. Number of rented second homes and beds per municipality in the Costa Brava area (2004).

\section{Second Percentage}

homes

\begin{tabular}{lrrlrr} 
Torroella de Montgri & 1,377 & 14.39 & Torroella de Montgri & 6,692 & 15.57 \\
Lloret de Mar & 1,164 & 12.17 & Lloret de Mar & 4,943 & 11.50 \\
Castell-Platja d'Aro & 752 & 7.86 & l'Escala & 4,113 & 9.57 \\
Sant Feliu & 718 & 7.51 & Castell-Platja d'Aro & 3,013 & 7.01 \\
l'Escala & 666 & 6.96 & Llançà & 2,781 & 6.47 \\
Castelló d'Empúries & 610 & 6.38 & Castelló d'Empúries & 2,652 & 6.17 \\
Roses & 598 & 6.25 & Roses & 2,609 & 6.07 \\
Llançà & 593 & 6.20 & Sant Feliu & 2,334 & 5.43 \\
Pais & 494 & 5.16 & Pais & 2,291 & 5.33 \\
Palafrugell & 446 & 4.66 & Palafrugell & 2,218 & 5.16 \\
Blanes & 339 & 3.54 & Calonge & 1,427 & 3.32 \\
Tossa de Mar & 319 & 3.33 & Blanes & 1,414 & 3.29 \\
Calonge & 316 & 3.30 & Tossa de Mar & 1,152 & 2.68 \\
Palamós & 281 & 2.94 & Palamós & 1,049 & 2.44 \\
Begur & 191 & 2.00 & Begur & 993 & 2.31 \\
El Port de la Selva & 125 & 1.31 & El Port de la Selva & 593 & 1.38 \\
Others & 578 & 6.04 & Others & 2,708 & 6.30 \\
\hline
\end{tabular}

Source: Statistics National Institute of Spain (INE).

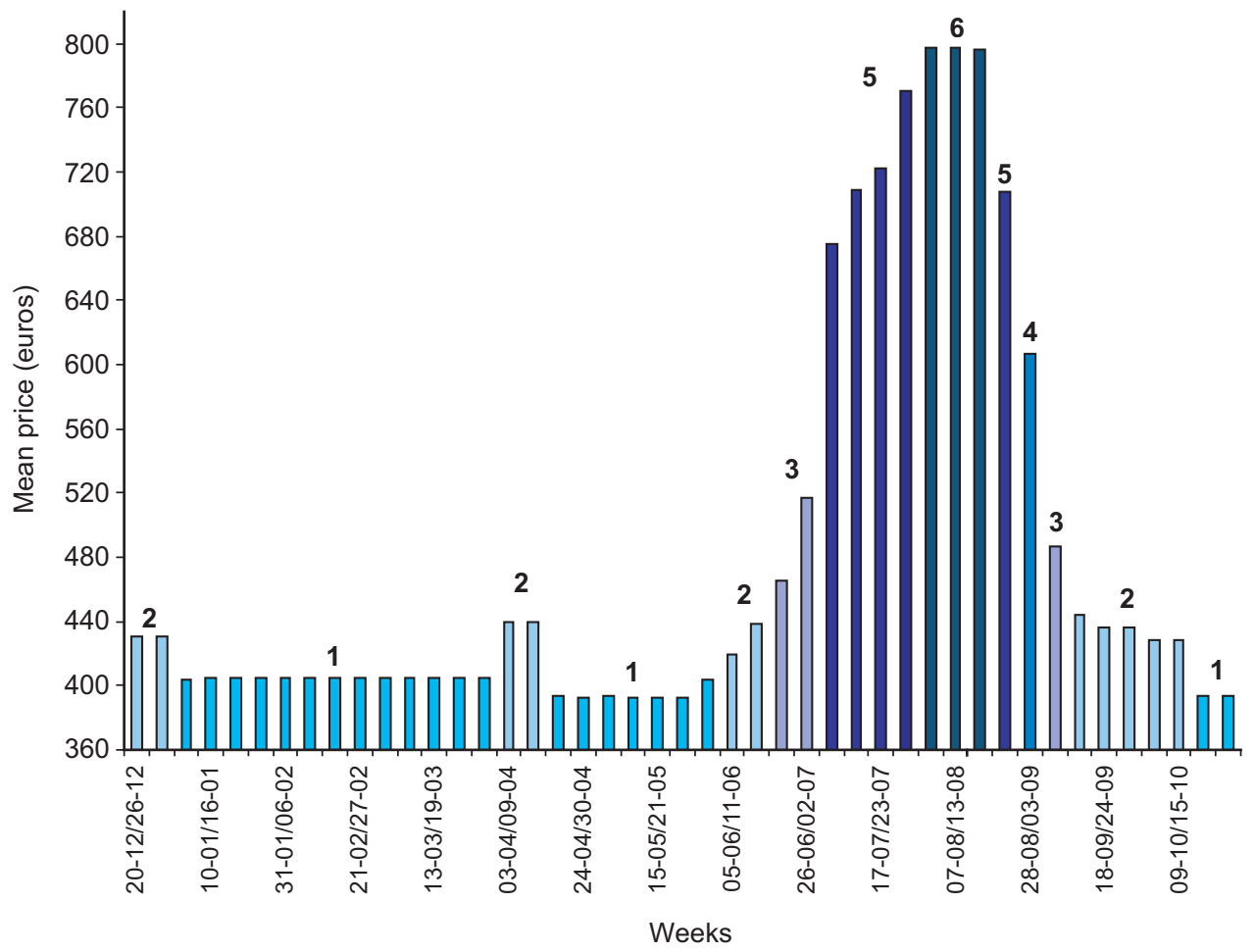

Figure 1. Mean price evolution throughout 2004 (euro). 
(1) Low season: January, February, March, April (except for the 2 weeks of Easter), May and the second fortnight of October.

(2) Medium season: Christmas (last fortnight of December), Easter (the second fortnight of April in 2004), the first fortnight of June; the third and fourth weeks in September and the first fortnight of October.

(3) Medium-bigh season: the second fortnight of June and the second week of September.

(4) High season: the first weekend in September.

(5) Upper-high season: the first, second and third weeks in July and the last weekend in August.

(6) Extreme-high season: the fourth week of July and the first, second and third weeks of August.

As a matter of fact, the analysis above is eminently descriptive and an in-depth and strictly seasonal approach is performed by means of regression analysis.

\section{Results}

The fit of the models is very good in both cases according to adjusted $R^{2}\left(R^{2}=0.804\right.$ and $\left.R^{2}=0.810\right)$ and the $p$-value for the $F$-test is smaller than $1 \%$. Most of the variables are significant at the $5 \%$ level. There are no multicollinearity or heteroskedasticity problems. Dummy coefficient values need to be converted into price elasticities by means of the transformation $e^{\beta}-1$, which is interpreted as the percentage variation in the price paid with respect to the reference category (Kennedy, 1998). The results of both regressions involving adjusted coefficients (elasticities) and $p$-values are shown in Table 3. The main results are described as follows and every interpretation of each variable is considered under ceteris paribus conditions:

- Rooms: an extra room represents a $13.64 \%$ rise in the final price of the second home, and for the wholesaler the percentage rise in price is similar $(14.98 \%)$.

- Home size: the rental price of accommodation of more than $100 \mathrm{~m}^{2}$ is $25.49 \%$ higher than a holiday home of between 0 and $50 \mathrm{~m}^{2}$, which is the reference category, and for wholesaler data the price is $13.23 \%$ higher. Also, a second home of $50-100 \mathrm{~m}^{2}$ is $6.8 \%$ higher than the reference home $\left(0-50 \mathrm{~m}^{2}\right)$. In the wholesaler sample, this percentage is $3.8 \%$.

- Terrace/garden size: a second home with a garden or terrace larger than $30 \mathrm{~m}^{2}$ increases the price by $9.16 \%$ in comparison to another home with a $0-10 \mathrm{~m}^{2}$ size garden (3.3\% in the wholesaler case). There is no significant difference between accommodation with a garden/terrace of between 10 and $30 \mathrm{~m}^{2}$ and the reference group $\left(0-10 \mathrm{~m}^{2}\right)$ in both regressions.

- Common garden: the availability of this attribute represents a price increase of $7.75 \%$ in comparison to accommodation without it (not significant for wholesaler brochure data).

- Housing type: the rental price of a holiday apartment is $10.90 \%$ less than the price of a terraced house $(14.54 \%$ less in the wholesaler data). A detached house is $13.82 \%$ higher priced than a terraced house $(11.8 \%$ higher in the wholesaler data). Therefore, apartments are the cheapest type 
Table 3. Hedonic regressions with whole data and wholesaler data.

Whole data

Coefficients Std $p$-value Coefficients Std $p$-value error

(intercept)

Rooms

home size: $50-100 \mathrm{~m}^{2}$

home size: $101 \mathrm{~m}^{2}$ and more

terrace/garden size: $10-30 \mathrm{~m}^{2}$

terrace/garden size: $31 \mathrm{~m}^{2}$ and more

common garden

detached house

apartment

car park

swimming pool

beach distance: 0-30 m

beach distance: $31-100 \mathrm{~m}$

beach distance: $101-300 \mathrm{~m}$

beach distance: $301-1,000 \mathrm{~m}$

beach distance: 1,001-3,000 m

beach distance: 3,001-5,000 m

sea views

Begur

l'Escala

l'Estartit

Llançà

Lloret

Castell-Platja d'Aro

Roses

Calonge

St Feliu de Guixols

wholesaler

medium season

medium-high season

high season

upper-high season

extreme-high season

\begin{tabular}{rrrrrr}
\multicolumn{1}{c}{485.33} & 0.054 & 0.001 & \multicolumn{1}{c}{505.05} & 0.041 & 0.001 \\
0.136 & 0.007 & 0.005 & 0.150 & 0.007 & 0.004 \\
0.068 & 0.015 & 0.023 & 0.038 & 0.014 & 0.038 \\
0.255 & 0.025 & 0.011 & 0.132 & 0.025 & 0.020 \\
0.012 & 0.013 & 0.115 & 0.011 & 0.013 & 0.112 \\
0.092 & 0.016 & 0.018 & 0.033 & 0.015 & 0.046 \\
0.078 & 0.012 & 0.017 & -0.012 & 0.012 & -0.102 \\
0.138 & 0.020 & 0.015 & 0.118 & 0.019 & 0.017 \\
-0.109 & 0.020 & -0.017 & -0.145 & 0.020 & -0.013 \\
-0.009 & 0.012 & -0.137 & -0.013 & 0.011 & -0.085 \\
0.257 & 0.014 & 0.006 & 0.204 & 0.013 & 0.007 \\
0.554 & 0.045 & 0.010 & 0.601 & 0.044 & 0.009 \\
0.391 & 0.032 & 0.010 & 0.367 & 0.031 & 0.010 \\
0.343 & 0.031 & 0.010 & 0.328 & 0.029 & 0.010 \\
0.197 & 0.028 & 0.016 & 0.212 & 0.026 & 0.013 \\
0.148 & 0.029 & 0.021 & 0.177 & 0.027 & 0.017 \\
0.034 & 0.033 & 0.098 & 0.103 & 0.030 & 0.030 \\
0.093 & 0.014 & 0.015 & 0.119 & 0.013 & 0.011 \\
-0.026 & 0.023 & -0.089 & -0.004 & 0.021 & -0.493 \\
-0.059 & 0.021 & -0.035 & -0.042 & 0.019 & -0.044 \\
0.138 & 0.062 & 0.048 & - & - & - \\
-0.083 & 0.019 & -0.021 & -0.106 & 0.016 & -0.015 \\
0.172 & 0.027 & 0.017 & 0.217 & 0.024 & 0.012 \\
0.178 & 0.043 & 0.026 & - & - & - \\
-0.033 & 0.025 & -0.076 & -0.016 & 0.022 & -0.135 \\
-0.057 & 0.041 & -0.070 & -0.206 & 0.036 & -0.016 \\
-0.248 & 0.038 & -0.013 & - & - & - \\
0.287 & 0.035 & 0.014 & - & - & - \\
0.110 & 0.017 & 0.017 & 0.108 & 0.016 & 0.016 \\
0.204 & 0.017 & 0.009 & 0.192 & 0.016 & 0.009 \\
0.579 & 0.017 & 0.004 & 0.628 & 0.016 & 0.003 \\
0.774 & 0.017 & 0.003 & 0.719 & 0.016 & 0.003 \\
0.973 & 0.017 & 0.003 & 0.906 & 0.016 & 0.003 \\
\hline & & & & &
\end{tabular}

of accommodation, followed by terraced houses, and detached houses are the most expensive when all other characteristics are the same.

- Car park: the availability of a cark par is one of the variables which are not significant in either regression in this analysis. Therefore, this is not a characteristic that influences the final price.

- Swimming pool: a second home with this attribute is $25.68 \% 6$ more expensive than accommodation without this facility $(20.43 \%$ for the wholesaler data).

- Sea views: the percentage price difference is $9.27 \%$ for the whole sample data and $11.93 \%$ for the wholesaler data. 
Table 4. Price differentials for the same second home: municipality and beach distance effect.

\begin{tabular}{llll}
\hline Municipality & Index & Distance to beach & Index \\
Castell-Platja d'Aro & 117.8 & $0-30 \mathrm{~m}$ & 155.4 \\
Lloret de Mar & 117.2 & $30-100 \mathrm{~m}$ & 139.1 \\
L'Estartit & 113.8 & $100-300 \mathrm{~m}$ & 134.3 \\
Castelló d'Empúries & 100 & $300-1,000 \mathrm{~m}$ & 119.7 \\
Begur & 97.4 & $1,001-3,000 \mathrm{~m}$ & 114.8 \\
Roses & 96.7 & $3,001-5,000 \mathrm{~m}$ & 100 \\
Calonge & 94.3 & More than $5,000 \mathrm{~m}$ & 100 \\
L'Escala & 94.1 & & \\
Llançà & 91.7 & & \\
Sant Feliu de Guíxols & 75.2 & & \\
\hline
\end{tabular}

Note: Items in italics were used as a reference in the econometric analysis.

- Beach distance: a wide range of seven increments has been created for this variable, which fits better in the model. In this analysis, a holiday home in front of the beach $(0-30 \mathrm{~m})$ is $55.42 \%$ more expensive than one situated $5 \mathrm{~km}$ from the beach (used as a reference). For the wholesaler, this difference is $60.14 \%$. The further the accommodation is from the beach, the lower the rental price. Thus, a second home located at $30-100 \mathrm{~m}$ from the beach is $39.11 \%$ more expensive than the reference second home. Table 4 shows the rest of the results for the next increments, where the price difference in percentage drops when accommodation is closer to the accommodation reference. Note that second homes located $3-5 \mathrm{~km}$ from the beach show no difference regarding the accommodation reference (in the first regression).

- Municipality: this variable shows whether there are price differences for identical accommodation in different municipalities. The reference municipality is Castelló d'Empúries. Six municipalities show significant differences in price with respect to Castelló d'Empúries. Using the first regression results, a second home in Llançà is around $8.3 \%$ cheaper, in L'Escala 6\% cheaper and in Sant Feliu de Guíxols 24.8\% cheaper. On the other hand, Lloret (17-22\%), l'Estartit (13.8\%) and Castell-Platja d'Aro $(17.8 \%)$ are significantly more expensive than Castelló d'Empúries. Both the beach distance and municipality effects are displayed in Table 4 using a price index.

- Seasonality: according to the previous descriptive analysis, the prices of the available weeks have been grouped into six periods, ranging from low season to extreme-high season. In this case, as it is also a dummy, the reference group is the low season. Thus, for the whole data the range of significant price difference regarding low season is from $11 \%$ in the medium season to $97 \%$ in the extreme-high season. The last percentage means, for instance, that to hire accommodation in a week in February or in the first week of August almost doubles the price. The rest of the percentages are shown in Table 3. Similar results have been obtained with the wholesaler data.

- Star rating: this variable appears only in the analysis of the wholesaler data. Despite the possible well-known problem of multicollinearity, because star 
rating can include the aforementioned variables (Sinclair et al, 1990), the coefficient results of these variables between whole data and wholesaler data indicate no relevant differences. Therefore, star rating explains more unobserved characteristics such as comfort, furniture quality or noise levels. Thus, 2-star accommodation is $9.39 \%$ more expensive than 1-star accommodation, ceteris paribus. A second home catalogued as 3 stars is $33.94 \%$ more expensive than low-quality accommodation (1 star). Finally, a 4-star holiday home is $166.10 \%$ more expensive than 1-star accommodation more than double the price.

- Distribution channel: here a distinction is made between data that come from a single source, a well-known international intermediary wholesaler, and data from other intermediaries via the Internet. The aim is to see whether the intermediary wholesaler (69\% of the data) applies different rates, despite the second homes having the same attributes. What is certain is that accommodation with the same characteristics is $28.69 \%$ more expensive when booked through the wholesaler than when booked through intermediaries via the Internet. ${ }^{7}$

\section{A simple theoretical framework for a high-market-share intermediary's influence in the market}

According to the results above, wholesalers have a significant impact on price in the second-home rental market. Here, we consider asymmetric information (in terms of moral hazard) when consumers choose a second-home rental through the Internet or a physical intermediary. A well-known intermediary wholesaler with a high market share bears the risk of uncertainty when suppliers are chosen that offer quality standards with regard not only to house characteristics but also to cleanliness, security and basic services. These kinds of guarantees are important to consumers when they decide to rent a house without having the opportunity of checking its characteristics in situ because of the distance between consumer and supplier. This guarantee offered by a reputable wholesaler implies a transaction cost reflected in the final price (Spulber, 1999; Williamson and Masten, 1999).

To shed some light on the classic adverse selection problem, we build up a theoretical approach. Akerlof considers the market for lemons (1970), in which suppliers know product quality but buyers do not. An extension of this setting appears in Biglaiser (1993), where an intermediary is introduced who plays the role of an expert in determining product quality for the consumer. An intermediary has more incentives to invest in assessing product quality than an individual buyer. Moreover, he or she has greater incentives to report the quality of the good than an ordinary supplier. Therefore, an intermediary benefits from finding out the quality of the goods sold, since this is a way of investing in his or her own reputation.

Here, we adapt Biglaiser's model to show how some consumers could pay more and nevertheless achieve higher welfare levels because of the high-marketshare intermediary presence. Two types of buyer valuations can be distinguished using the characteristics in the previous hedonic price model. In our context, 
we consider the intermediary with a high market share and previous nomenclature:

$$
v_{1}=f\left(D_{i}^{i o c}, D_{i}^{l o c}, D_{i t}^{s e a}\right) \text { and } v_{2}=f\left(D_{i}^{i o c}, D_{i}^{l o c}, D_{i}^{\text {int }}\right)
$$

where $D_{i}^{\text {int }}$ is the intermediary that offers extra information through star rates, guarantees and a trustworthy reputation; ${ }^{8} v_{1}$ is a buyer's valuation for a second home without considering an intermediary; and $v_{2}$ is a buyer's valuation for the same second home with the same characteristics but adding the intermediary. Considering the intermediary's positive contribution to consumers:

$$
\frac{\Delta v_{2}}{\Delta D_{i}^{\text {int }}}>0 \text { and } v_{2}=v_{1}+\frac{\Delta v_{2}}{\Delta D_{i}^{\text {int }}} \text { so } v_{2}>v_{1}
$$

Consider an infinitely lived consumer and a discount factor $\delta=e^{-r}$, where $r$ is the rate of discount. The seller knows the quality of the good and receives a rent of $p_{1}$. The intermediary obtains a fee $K$ for his services. A proportion $\lambda$ of sellers will trade their second homes through an intermediary. This implies that consumers pay $p_{2}=p_{1}+K$, while a proportion $(1-\lambda)$ of sellers will rent directly to final consumers. We first analyse consumer welfare $\left(C_{w}^{1}\right)$ without an intermediary:

$$
C_{w}^{1}=\left[(1 /(1-\delta)]\left(v_{1}-p_{1}\right)\right.
$$

Now a consumer with an intermediary in the market $\left(C_{w}^{2}\right)$ :

$$
C_{w}^{2}=\left[\left(1 /(1-\delta) \operatorname{I}\left(v_{1}-p_{1}\right)+(1-\lambda)\left(v_{2}-p_{2}\right)\right]\right.
$$

Finally, considering the empirical evidence above:

$$
v_{2}-p_{2}>v_{1}-p_{1}, v_{2}-v_{1}>p_{2}-p_{1} \text {, so } \frac{\Delta v_{2}}{\Delta D_{i}^{\text {int }}}>K
$$

This means that the marginal value of an intermediary for consumers is higher than the intermediary's service cost. Even more, in terms of welfare, if both $\lambda$ and $\delta$ are not close to zero, then it is possible that $C_{w}^{2}>C_{w}^{1}$. Thus, with intermediaries we can distinguish two types of consumers with different behaviour. It is a possibility that, overall, in this market customers may be better with an intermediary.

\section{Discussion}

The previous results confirm the importance of the original hypothesis set out at the beginning of this paper. Thus, the beach distance effect is a barely used and flexible variable that enhances information about the strategic location of tourist accommodation across a municipality. The sea views variable has offered 
an interesting result in terms of providing a value for coast and landscape throughout the Costa Brava area. House type is another original variable that has never been studied before. The results for detached housing, terraced housing and apartments are as one would expect. The advantages of a detached house compared to a terraced house, and especially an apartment, in terms of privacy implies a price variation that cannot be described by the other variables included in the model. Thus, using the coefficients found, one can obtain a concrete value for this privacy.

This paper provides results that can be useful for policy makers and stakeholders. By considering the municipality effect, local governments can assess the tourism policies adopted in the past and consider future strategies. The municipality effect in the final price of second homes is the result of several elements. Public and private goods in tourist destinations affect the final price received by tourism firms. Rigall-I-Torrent and Fluvià $(2007,2011)$ argue both theoretically and empirically that local public goods and services (street lighting, public squares, promenades, local police, ...) and private goods exert a positive influence on tourism firms' prices.

For the public sector, there is evidence that revenue from property taxes in tourism municipalities in the Costa Brava with many public goods and services is, on average, higher than in non-tourist municipalities with less public goods (Garriga et al, 2008). ${ }^{9}$ Besides, the paper's results can be used to assess new public investments for local municipalities.

On the other hand, Hudson (2008) argues that a premium price can be set in some allocations as a result of a good reputation in terms of brand image. Public and/or private promotion expenses, environmental aspects like beach quality or landscapes, transport networks, international events and so on are observed non-market values that could create this premium pricing.

Therefore, municipality policy makers can gain information about its position in the marketing (brand image) and/or the implicit quantity and quality public goods ranking that they are offering compared to other towns. The beach distance effect set out in this article can provide current market information for public and private institutions to value properties and apply suitable taxes (public) or rates (private) because of suitable location.

Another interesting finding is star rating in wholesaler data and its price segmentation effect on second-home rentals. Setting a standard ranking by tourist public institutions could help the sector in the near future to homogenize criteria in order to classify rented accommodation into quality categories in the same way as has been applied throughout to hotels. Consumers would obtain better information to choose according to their preferences and budget constraints. Marketers could offer prices according to trustworthy quality.

Intermediaries play a significant role in second-home markets. This is reflected in the final price. Wholesalers offer extra value because of star ratings, extra information and offices for customers, as well as a trustworthy reputation. The alternative considered in this study has been Internet information using different intermediary sources. The difference between using one channel or another lies in the transparency achieved in terms of price and characteristics. The value created by the wholesaler shows that consumers are willing to pay more for the wholesaler's services for a similar second home, and this can even contribute to improve overall consumer welfare. Focusing on the second 
regression, one realizes that the intermediary data hardly change the coefficients of the second-home characteristics taken into account in the first model. This means that the hedonic values of characteristics are consistent throughout the analysis.

Obviously, price effects on second homes cannot be explained by elements considered in the regression analysis alone. According to Skak (2004), public policies restricting or not restricting ownership of second homes because of being a scarce good has implications on prices on the rental market. On a different matter, sociological reasons are behind the decision to rent a second home according to owners' profiles and the varying proportion offered in the second-home market. For example, Bieger et al (2007) argue that young owners rent out more because there is less usage of these homes and they are more likely to be put up for rent.

\section{Concluding remarks}

Second-home rentals are one of the most important but least exploited areas of the tourist accommodation market when compared with hotels. This kind of accommodation has grown in importance gradually in the last years, and it is an alternative to hotels in Spain, where the number of tourists is still increasing. The sample of rental prices used in this study has allowed us to analyse the most significant characteristics that influence the final price of rented tourist accommodation in a representative tourist area (Costa Brava). The hedonic pricing methodology has been used in this analysis.

The variables that have the most important effect on the final price of rented accommodation are the number of bedrooms, area in square metres, private or common garden, the type of accommodation, swimming pool, sea views, distance to the beach, the municipality where the home is located, the intermediary through whom the booking is made and, of course, the season of the year. All these variables have a significant effect on the final rental price. A theoretical framework for the role of intermediaries has been set up to explain that, for some consumers, the value of an intermediary more than compensates for the extra payment.

Further discussion in terms of public and private policy strategies for the near future, such as standardizing star rating for the second-home rental market and the evaluation of public goods and brand image at the local level, is considered here. Future research on the relationship between hotels and second homes as tourist accommodations may be of interest.

\section{Endnotes}

1. In housing censuses carried out by the National Statistics Institute (INE), it is difficult to distinguish between owner-used tourist accommodation, rented tourist accommodation and unoccupied housing that is for sale.

2. House size and garden size have been analysed through three qualitative increments (small, medium, large) according to a proportional distribution of the sample collected.

3. Other characteristics that can influence the final price have not been explored in this study as they are imprecise variables and/or are not available for all holiday homes: for example, the proximity of leisure centres (sports centres, children's fun parks, activity centres), decorative details and interior comfort of the accommodation, distance to the town centre, ease of access 
and the distance to basic services such as supermarkets and health services.

4. The regression model for the wholesaler data is as follows:

$$
\begin{aligned}
& \ln \text { price }_{i t}=\beta_{0}+\beta_{1} \text { rooms }+\sum_{i=2}^{4} \beta_{i} m^{2} \text { area }+\sum_{i=5}^{7} \beta_{i} m^{2} \text { terrace }+\beta_{8} \text { comgarden }+ \\
& \sum_{i=9}^{11} \beta_{i} \text { bousingtype }+\beta_{12} \text { carpark }+\beta_{13} \text { swimpool }+\sum_{i=14}^{20} \beta_{i} \text { distbeach }+\beta_{21} \text { seaviews }+ \\
& \sum_{i=22}^{31} \beta_{i} \text { municipality }+\sum_{i=32}^{35} \beta_{i} \text { stars }+\sum_{i=36}^{41} \beta_{i} \text { seasonality }_{i t}+u_{i t}
\end{aligned}
$$

where $i$ identifies each holiday home, $t$ the holiday period within the seasonality variable, $u_{i t}$ the perturbation term for each holiday home $i$ and according to the period $t$. $\beta_{i}$ defines the coefficients for each of the characteristics studied.

5. This distribution is according to availability of data where it is obtained easily through brochures or with more difficulty through the Internet. Besides, data were collected temporally without any discount or other promotion effects on overall price.

6. As an example of transformed coefficients, for the swimming pool variable with an initial coefficient of 0.2286 the transformation is $e^{(0.2286)}-1=0.2568=25.68 \%$.

7. Several and varied Internet intermediaries are used in this study. Some data are not available for some variables.

8. The empirical data collected by the wholesaler offer more details than the Internet data.

9. Of course, this paper considers only the positive relationship between the provision of local goods and services by the government and second-home rental prices. Nevertheless, this paper does not deal with the negative aspects referred to in Müller et al (2004), such as the costs incurred by the local government to preserve public goods and services, the increase in property prices and the cost of local private goods and services to local inhabitants.

\section{References}

Akerlof, G. (1970), 'The market for lemons: quality uncertainty and the market mechanism', Quarterly Journal of Economics, Vol 84, No 3, pp 488-500.

Benson, E.D., Hansen, J.L., Schwartz, A.L. Jr, and Smersh, G.T. (1998), 'Pricing residential amenities: the value of a view', Journal of Real Estate Finance and Economics, Vol 16, No 1, pp 55-73.

Berndt, E.R. (1990), The Practise of Econometrics: Classic and Contemporary, Addison-Wesley Publishing Company, New York.

Bieger, T., Beritelli, P., and Weinert, R. (2007), 'Understanding second home owners who do not rent: insights on the proprietors of self-catered accommodation', Hospitality Management, Vol 26, pp 263-276.

Biglaiser, G. (1993), 'Middlemen as experts', Rand Journal of Economics, Vol 24, pp 212-223.

Bover, O., and Velilla, P. (2002), 'Hedonic house prices without characteristics: the case of new multiunit housing', Working Paper Series No 117, European Central Bank.

Coppock, J.T. (1977), Second Homes: Curse or Blessing?, Pergamon, Oxford.

Espinet, J.M., Sáez, M., Coenders, G., and Fluvià, M. (2003), 'Effect on prices of the attributes of holiday hotels: a hedonic prices approach', Tourism Economics, Vol 9, No 2, pp 165-177.

Garriga A., Fluvià, M., and Rigall-I-Torrent, R. (2008), 'Déficit en la provision local de servicios públicos y tipología municipal' [Deficit on public service endowments and municipality typology], Revista de Economía Aplicada, Vol 16, No 48, pp 111-132.

Hamilton, J.M. (2007), 'Coastal landscape and the hedonic price of accommodation', Ecological Economics, Vol 62, No 3-4, pp 594-602.

Haroutunian, S., Mitsis, P., and Pashardes, P. (2005), 'Using brochure information for the hedonic analysis of holiday packages', Tourism Economics, Vol 11, No 1, pp 69-84.

Hudson, S. (2008), Tourism and Hospitality Marketing, SAGE Publications, London.

Kennedy, P. (1998), A Guide to Econometrics, Blackwell Publishers, Oxford.

Marjavaara, R., and Müller, D.K. (2007), 'The development of second home's assessed property values in Sweden 1991-2001', Scandinavian Journal of Hospitality and Tourism, Vol 7, No 3, pp 202222.

Müller, D.K., Hall, C.M., and Keen, D. (2004), 'Second home tourism impact, planning and management', in Hall, C.M., and Müller, D.K., eds, Tourism, Mobility and Second Homes. Between Elite Landscapes and Common Ground, Channel View Publications, Clevedon, pp 15-32. 
Pompe, J., and Rinehart, J. (1994), 'Estimating the effect of wider beaches on coastal housing prices', Ocean and Coastal Management, Vol 22, pp 141-152.

Rigall-I-Torrent, R., and Fluvià, M. (2007), 'Public goods in tourism municipalities - formal analysis, empirical evidence and implications for sustainable development', Tourism Economics, Vol 13, No 3, pp 361-378.

Rigall-I-Torrent, R., and Fluvià, M. (2011), 'Managing tourism products and destinations embedding public good components: a hedonic approach', Tourism Management, Vol 32, No 2, pp 244-255.

Rosen, S. (1974), 'Hedonic prices and implicit market: product differentiation in pure competition', Journal of Political Economy, Vol 82, pp 34-55.

Saló, A. (2005), 'Estudi sobre l'habitatge a la demarcació de Girona: habitatges principals, segones residències i apartaments turístics' [Analysis of housing in Girona province: main homes, second homes and tourist apartments], PhD Dissertation, Universitat de Girona, Girona.

Sinclair, T., Clewer, A., and Pack, A. (1990), 'Hedonic prices and the marketing of package holidays: the case of tourism resorts in Malaga', in Ashworth, G.J., and Goodall, B., eds, Marketing Tourism Places, Routledge, London, pp 85-103.

Skak, M. (2004), 'Restricting ownership of vacation homes', Tourism Economics, Vol 10, No 4, pp $435-447$.

Spulber, D.F., (1999), Market Microstructure: Intermediaries and the Theory of the Firm, Cambridge University Press, New York.

Thrane, C. (2005), 'Hedonic price models and sun-and-beach package tours: the Norwegian case', Journal of Travel Research, Vol 43 (February), pp 302-308.

Vinuesa, J. (2005), 'Dinámica demogràfica, mercado de vivienda y territorio [Demographic dynamics, housing market and territory]', Papeles de Economía Española, Vol 104, pp 253-269.

Williamson, O.E., and Masten, S.E. (1999), The Economics of Transaction Costs, Edward Elgar Publishing, London. 